\title{
The West Island Site (41MXI65)
}

Kevin King

Mike Turner

Follow this and additional works at: https://scholarworks.sfasu.edu/ita

Part of the American Material Culture Commons, Archaeological Anthropology Commons, Environmental Studies Commons, Other American Studies Commons, Other Arts and Humanities Commons, Other History of Art, Architecture, and Archaeology Commons, and the United States History Commons

Tell us how this article helped you.

This Article is brought to you for free and open access by the Center for Regional Heritage Research at SFA ScholarWorks. It has been accepted for inclusion in Index of Texas Archaeology: Open Access Gray Literature from the Lone Star State by an authorized editor of SFA ScholarWorks. For more information, please contact cdsscholarworks@sfasu.edu. 


\section{The West Island Site (41MXI65) \\ Creative Commons License \\ (c) $($ ) $(9)$}

This work is licensed under a Creative Commons Attribution-NonCommercial 4.0 International License 


\section{The West Island Site (41MX65)}

Kevin King and Mike Turner

\section{INTRODUCTION AND SETTING}

This paper describes a set of artifacts collected from the West Island site, a poorlyknown Titus phase cemetery in Ellison Creek Reservoir. The site is on a small knoll adjacent to a small spring branch that flows into the now-inundated Ellison Creek, a tributary of Big Cypress Creek (Figure 1).

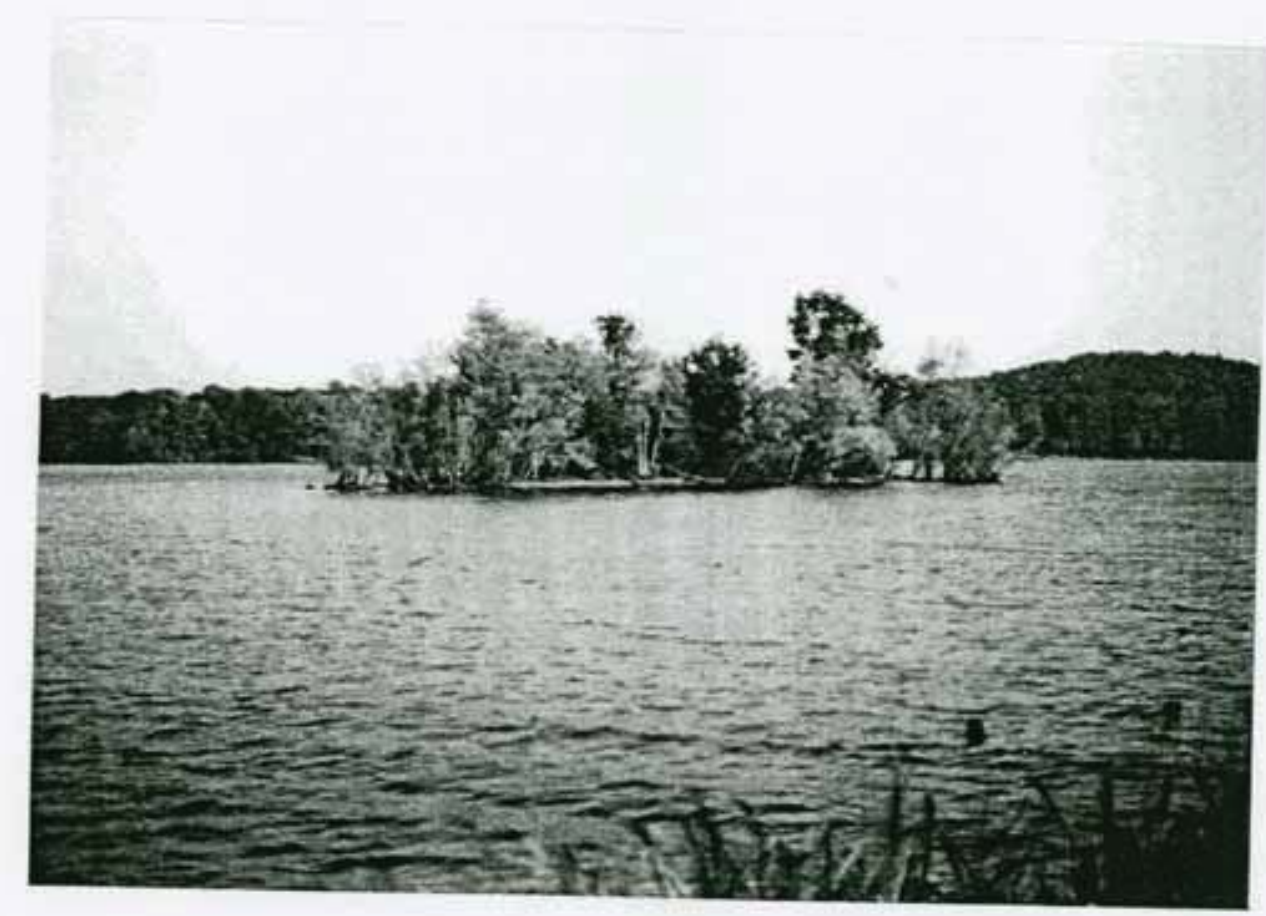

Figure 1. The West Island Site, Morris County, Texas.

The site knoll is now no more than one foot $(30 \mathrm{~cm})$ above the normal pool elevation of Ellison Creek Reservoir, and it is usually totally submerged. Up to five feet (1.52 meters) of white sand caps the knoll, and overlies the clay subsoil. Due to continued submergence, the knoll is being eroded by the reservoir, and consequently many stone tools and pieces of lithic debris are present along the water's edge. Dart points and arrowpoints have been found at the site, along with some pottery sherds, but no groundstone implements. Small amounts of charcoal were found around the top of the knoll in pockets of modern mussel shell and gravels, but its association with the site deposits is unknown. No middens are known to be present on the knoll. 
The West Island site has been previously dug by private collectors sometime before 1965. Turner (1978:Figure 33) had examined some of the site collections, and reported that ceramic vessels of the types Avery Engraved, Bailey Engraved, Bullard Brushed, Cowhide Stamped, Harleton Appliqued, Hodges Engraved, Karnack Brushed-Incised, Maydelle Incised, Ripley Engraved, Simms Engraved, Taylor Engraved, and Wilder Engraved were present in an unknown number of burials. These types of decorated ceramics are characteristic of the Titus phase, which dates from about 1400 to the 1600 s (Thurmond 1990; Perttula 1992).

\section{SITE INVESTIGATIONS}

Our investigations of the West Island site were conducted between February and September 1986. Upon initial inspection of the site, two large circular depressions were noted on the knoll. Troweling through the backdirt in the depressions established that not only were the depressions actually potholes previously dug in aboriginal graves at the site, but that artifacts missed in the potholing were encountered below the backdirt in both depressions. Four days were spent excavating the remnants of the burials-- here labelled burial \#1 and \#2.

\section{Grave Locations and Descriptions}

Burial \#1 was found at the southeast end of the knoll. After several pottery sherds (mainly body sherds) were found in the backdirt, a $3 \times 3$ foot $(0.92 \times 0.92$ meters) unit was laid out over the hole. Troweling the unit produced four ceramic vessels (vessels \#1-4) side-by-side at what was the west end of the burial at $50 \mathrm{~cm}$ below the surface. No other artifacts were found in the unit, and no human remains were preserved in the burial fill. Excavation of Burial \#1 was very difficult because of the constant flow of water into the excavation unit.

Burial \#2, located along the northeast shore, was identified by troweling in a large circular depression visible at the water's edge. Excavation of another $3 \times 3$ foot unit $(0.92 \times$ 0.92 meters) at this depression also encountered four ceramic vessels (\#5-8). These were $29 \mathrm{~cm}$ below the bottom of the pothole, about $55 \mathrm{~cm}$ below the ground surface. All four ceramic vessels were found clustered together at the west end of the burial. A small Gary dart point was recovered from inside vessel \#7. Again, no human remains were found preserved with Burial \#2.

Because of previous potholing, the graves were not complete. They did appear to be those of single individuals, based on the number of artifacts retrieved from them and their burial position. They were oriented east-west, the body probably supine with the head to 
the east (Turner 1978:105). The east-west placement of the burials at West Island is a common and general characteristic of Titus phase cemeteries in Northeast Texas.

\section{THE ARTIFACTS}

This section describes the artifacts found with Burials \#1 and \#2 at the site, along with a small sample of material collected from the surface of the site by the authors. Artifacts of pottery, stone, and bone were recovered from West Island during the investigations discussed above.

\section{Pottery}

Eight pottery vessels were recovered from the site, vessels \#1-4 from Burial \#1, and vessels \#5-8 from Burial \#2. Each of the vessels is described below, with the exception of vessel $\# 4$, as this vessel was stolen before it could be thoroughly studied.

Vessel \#1, Untyped Cooking Jar

Decoration: Brushed rim and plain body

Height: $27 \mathrm{~cm}$

Rim Diameter: $25 \mathrm{~cm}$

Base Diameter: $7 \mathrm{~cm}$

Temper: Grog

Vessel \#2, Ripley Engraved Carinated Bowl

Decoration: Scroll and circle motif (Turner 1978:28)

Height: $14 \mathrm{~cm}$

Rim Diameter: $28 \mathrm{~cm}$

Base Diameter: $8 \mathrm{~cm}$

Temper: Shell

Vessel \#3, Harleton Applique Jar

Decoration: Rim is quadrilaterally lobed with three fillets centered under each other while the upper body has appliqued chevrons with horizontal applique fillets (Suhm et al. 1954: Plate D-28)

Height: $19 \mathrm{~cm}$

Rim Diameter: $16 \mathrm{~cm}$

Base Diameter: $7 \mathrm{~cm}$

Temper: Grog 

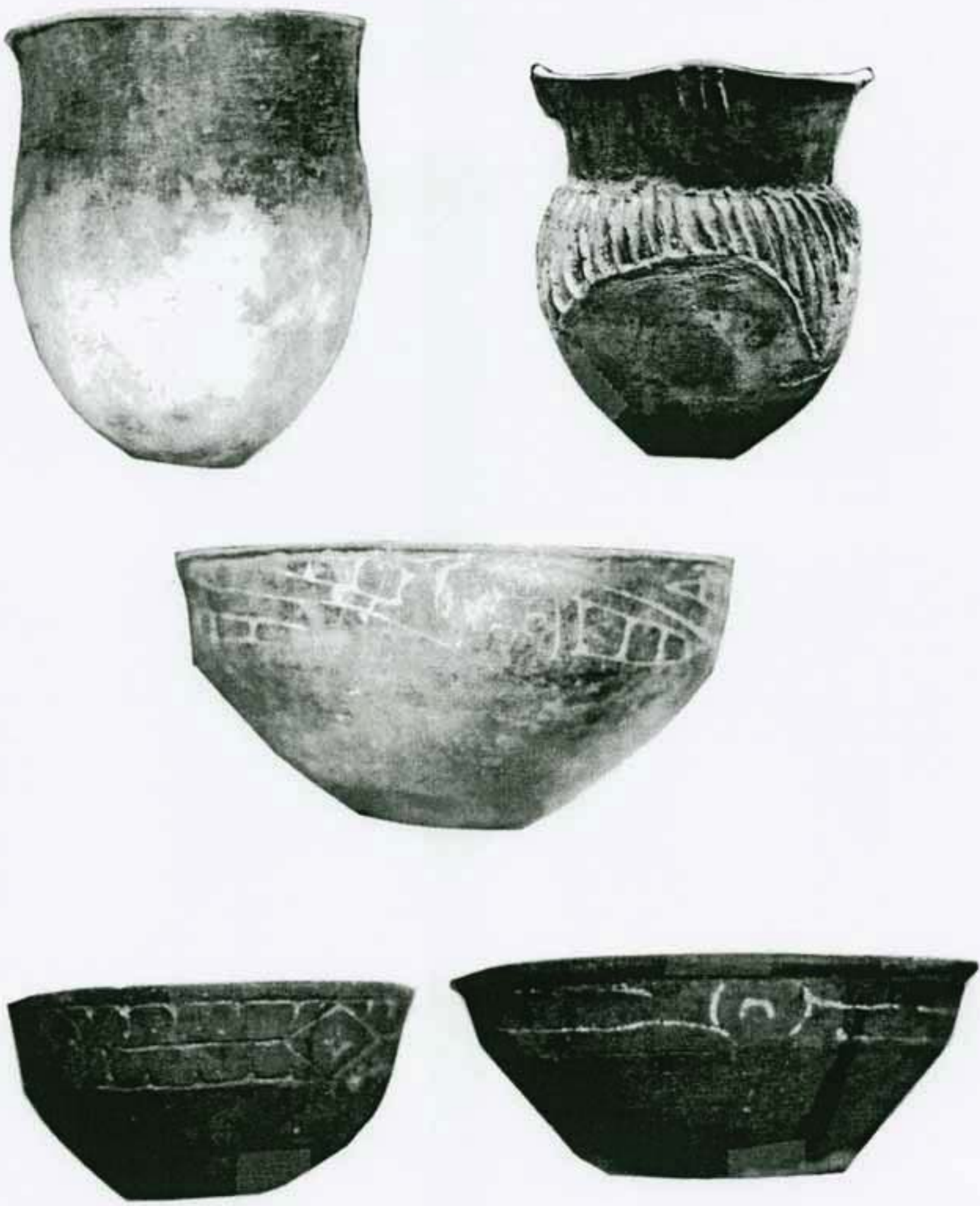

Figure 2. Selected vessels from the West Island Site. Top row, vessels \#1 and \#3; Middle row, vessel \#2; Bottom row, vessels \#7 and \#8. 
Vessel \#4, Avery Engraved, red-slipped

Height: N/A

Rim Diameter: $18 \mathrm{~cm}$

Base Diameter: $7 \mathrm{~cm}$

Temper: N/A

Comments: Further information not available because the vessel was stolen

Vessel \#5, Ripley Engraved Carinated Bowl

Decoration: Interlocking scroll rim motif (Turner 1978:28)

Height: $12 \mathrm{~cm}$

Rim Diameter: $24 \mathrm{~cm}$

Base Diameter: $7 \mathrm{~cm}$

Temper: Grog and Shell

Vessel \#6, Ripley Engraved Carinated Bowl

Decoration: Interlocking scroll rim motif (Turner 1978:28)

Height: $11 \mathrm{~cm}$

Rim Diameter: $27 \mathrm{~cm}$

Base Diameter: N/D

Temper: Grog

Comment: This vessel rested on the clay at the base of the grave. It was broken in several pieces that could not be conjoined; rim and base diameters could not be accurately measured. A red hematite pigment was applied to the engraved design.

Vessel \#7, Ripley Engraved Carinated Bowl

Decoration: Diamond pendant rim motif (Turner 1978:28)

Height: $7 \mathrm{~cm}$

Rim Diameter: $15 \mathrm{~cm}$

Base Diameter: $6 \mathrm{~cm}$

Temper: Bone and Shell

Comments: This vessel was found broken, and it is about 75 percent complete. The vessel is black in color, due to its being fired in a reducing atmosphere. A small Gary point was found inside the vessel. 


\section{Vessel \#8, Ripley Engraved Carinated Bowl}

Decoration: Scroll and circle rim motif (Turner 1978:28)

Height: $7 \mathrm{~cm}$

Rim Diameter: $19 \mathrm{~cm}$

Base Diameter: $6 \mathrm{~cm}$

Temper: Grit

Comments: A white pigment, probably kaolin, was applied to the engraved design. The use of a white pigment is not common on Ripley Engraved bowls with scroll and circle rim motifs.

One hundred fifty-seven sherds were collected from the site surface. Approximately 70 percent of the sherds were plain, with 49 rim and decorated pieces. Examples of decorative elements identified on the sherds include brushed, engraved, incised, pinched, punctated, appliqued, and red-slipped examples from Titus phase ceramic types (Figure 3); a number of the sherds were well-polished. Grog, grit, shell, and bone aplastics were used for tempers, similar to the whole vessels from burials \#1 and \#2.

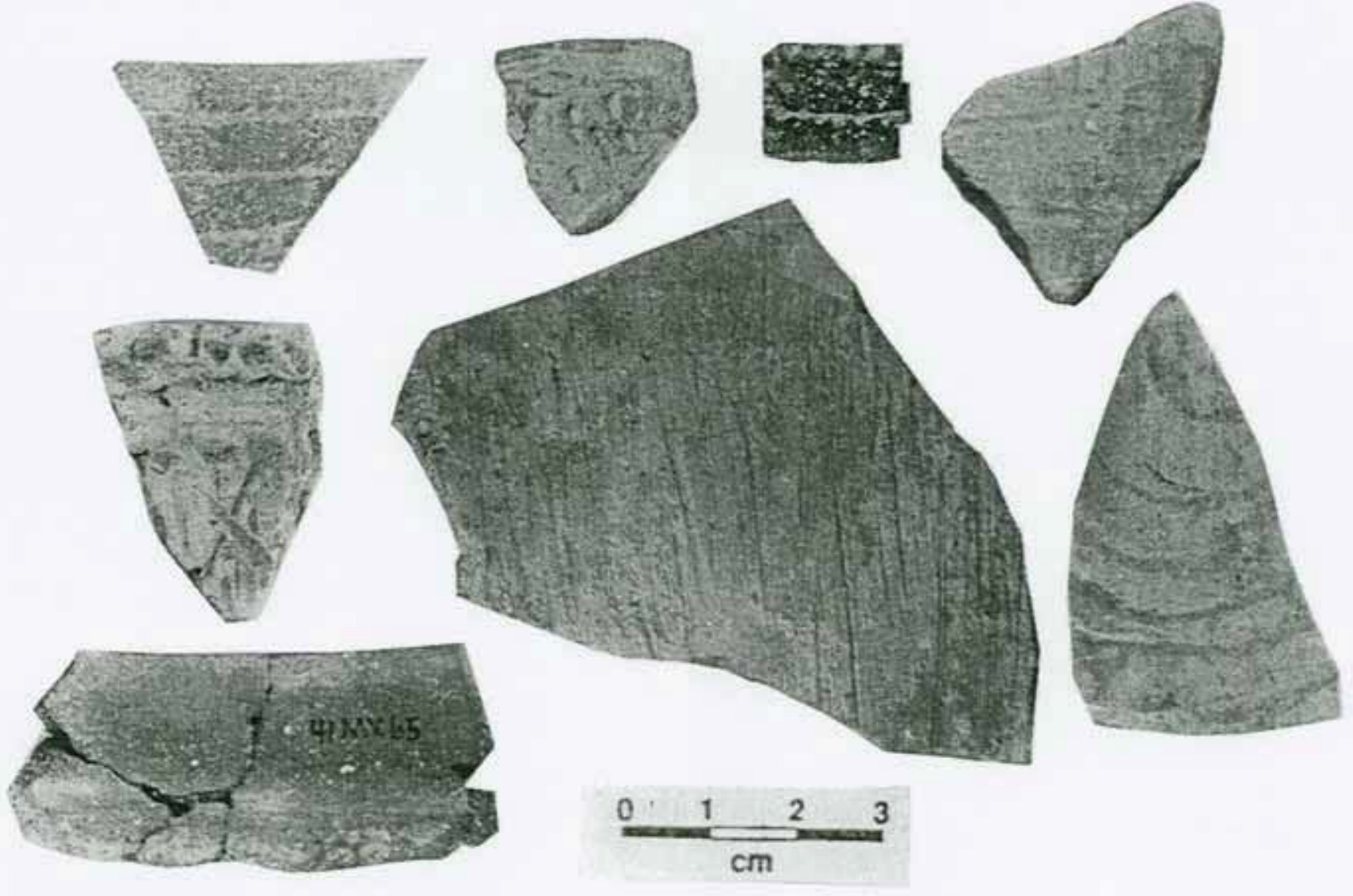

Figure 3. Rim and Decorated Sherds. 


\section{Lithics}

The lithic assemblage from the site consists of several hundred pieces of lithic debitage, four bifacial tools, 19 dart points, and six arrowpoints (Figure 4). The predominant lithic raw material is a locally-derived quartzite, along with petrified wood, and cherts. Novaculite from Red River gravels (Banks 1990) is also present at the site.
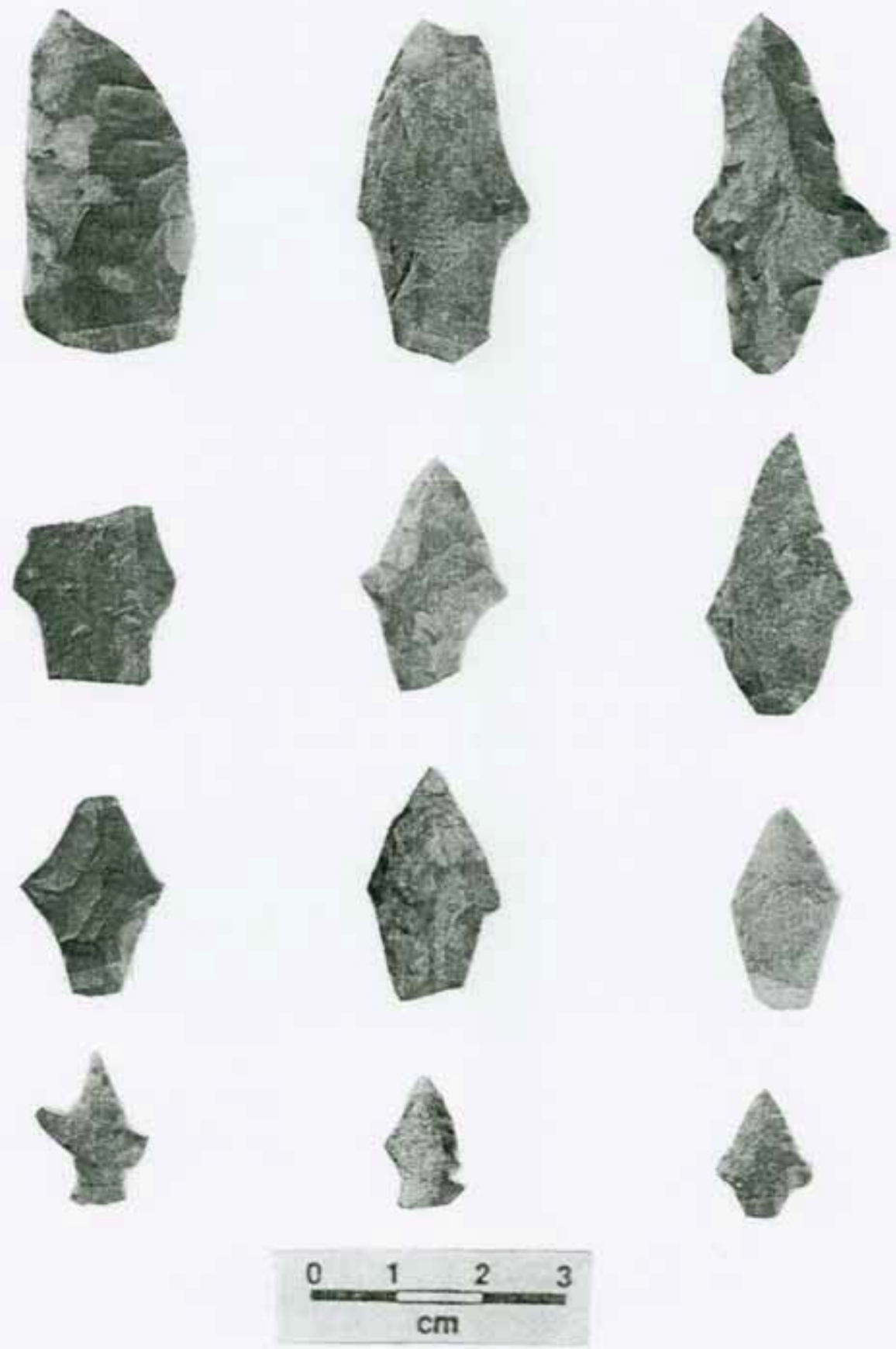

Figure 4. Selected Projectile Points from the West Island Site. 


\section{Notes on Northeast Texas Archaeology, No. 1}

The diagnostic dart points include: 16 Gary, one Ellis, one Kent, and one Yarbrough. Among the arrowpoints were three untyped fragments, a Friley, an Alba, and a Scallorn type. The frequency of Gary points in the projectile point assemblage suggests that a Late Archaic component is also present at the West Island site. Except for the one Gary point from burial \#2, all the diagnostic lithic tools were recovered from the site surface.

\section{Bone Artifacts}

A bone awl possibly made from a deer radius was found on top of a backdirt pile. It was poorly preserved, with most of the outside layer of bone badly eroded. The piece was $11.5 \mathrm{~cm}$ in length, with a basal width of $2.5 \mathrm{~cm}$.

A poorly preserved charred or blackened deer mandible, with teeth intact, was also found at the site. This mandible was found in Burial \#1 nestled between vessels \#3 and \#4.

\section{CONCLUDING STATEMENTS}

Our major objective in preparing this report was to provide information on the Titus phase burials at the West Island site. Our 1986 investigations confirmed that a severely disturbed Late Caddoan period cemetery was present at the site, as remnants of two burials with diagnostic Titus phase ceramics (Suhm et al. 1954; Turner 1978) were identified there. No midden deposits were detected at the site, and the number of individual burials that were once present there is unknown.

The artifacts found in the burials, particularly the ceramic vessels, are typical of the Titus phase. They included eight complete or fragmentary bowls and utility jars of the types Ripley Engraved, Harleton Applique, and Avery Engraved. The Ripley Engraved carinated bowls were the best represented in the small vessel sample. The red-slipped Avery Engraved bowl is considered an item of trade ware from the Texarkana or McCurtain phases on the Red River (Thurmond 1990). A scatter of Late Archaic projectile points and lithic debris also suggests that the site was utilized at other times than during the Titus phase, but the limited amount of such material is indicative only of an intermittent occupation.

\section{ACKNOWLEDGMENTS}

We would like to thank Ben Hay for his help, Bo Nelson for encouraging us to put our notes on paper, and we owe a special thanks to Dr. Timothy Perttula, who virtually took a combined set of jumbled notes and turned it into a readable report. 


\section{References}

Banks, Larry D.

1990 From Mountain Peaks to Alligator Stomachs: A Review of Lithic Sources in the Trans-Mississippi South, the Southern Plains, and Adjacent Southwest. Oklahoma Anthropological Society, Memoir No. 4. Norman.

Perttula, Timothy K.

1992 "The Caddo Nation": Archaeological and Ethnohistoric Perspectives. University of Texas Press, Austin.

Suhm, Dee Ann, Alex D. Krieger, and Edward B. Jelks

1954 An Introductory Handbook of Texas Archeology. Bulletin of the Texas Archeological Society 25 (whole volume).

Thurmond, J. Peter

1990 Archeology of the Cypress Creek Drainage Basin, Northeastern Texas and Northwestern Louisiana. Studies in Archeology No. 5. Texas Archeological Research Laboratory, The University of Texas at Austin.

Turner, Robert L.

1978 The Tuck Carpenter Site and Its Relation to Other Sites within the Titus Focus. Bulletin of the Texas Archeological Society 49:1-110. 